\title{
Annual cycle of dissolved silicate in Chesapeake Bay: implications for the production and fate of phytoplankton biomass*
}

\author{
Daniel J. Conley, Thomas C. Malone \\ Horn Point Environmental Laboratory, Center for Environmental and Estuarine Studies, University of Maryland System, \\ PO Box 775, Cambridge, Maryland 21613-0775, USA
}

\begin{abstract}
Seasonal variations in the distribution of dissolved inorganic nitrogen, silicon, and phosphorus along the salinity gradient of Chesapeake Bay from 1984 to 1988 suggest that dissolved silicate (DSi) controls the magnitude of diatom production during the spring bloom, causes the collapse of the spring bloom, and leads to changes in floristic composition. High sedimentation rates of chlorophyll biomass observed during this period could be due to Si-deficiency, suggesting that the supply of DSi may also control the flux of phytoplankton biomass to the benthos, an important parameter of seasonal oxygen depletion in the Bay.
\end{abstract}

\section{INTRODUCTION}

Diatom production can be limited by the availability of dissolved silicate (DSi), and DSi depletion relative to other major nutrients has been observed to select for non-siliceous flora (Kilham 1971, Schelske \& Stoermer 1971, Malone et al. 1980). As discussed by Officer \& Ryther (1980), this effect may be exacerbated by anthropogenic nutrient enrichment of coastal waters. In Chesapeake Bay, the input of new nutrients from the watershed appears to stimulate annual phytoplankton production (Boynton et al. 1982).

Nutrient input to the mainstem of the Bay (see Fig. 1) is primarily driven by the flow of the Susquehanna River, which peaks during spring (Schubel \& Pritchard 1986). The annual cycle of phytoplankton production in Chesapeake Bay is characterized by 2 phases, a spring biomass maximum in April-May supported by riverine nutrient inputs (Malone et al. 1988) and a summer productivity maximum supported by benthic nutrient regeneration (Kemp \& Boynton 1984). Although diatoms comprise 80 to $90 \%$ of algal abundance during the spring biomass maximum in Chesapeake Bay (Sellner \& Brownlee 1988) and may account for about $50 \%$ of annual phytoplankton production (D'Elia et al. 1983),

\footnotetext{
- UMCEES Contribution No. 2296
}

evaluations of nutrient-limited phytoplankton production have not examined DSi limitation (Boynton et al. 1982, D'Elia et al. 1986). In several bay-wide surveys along the salinity gradient of the mainstem, Fisher et al. (1988) observed significant removal of DSi inputs (40 to $100 \%)$ and noted that DSi concentrations were accasionally ( 5 to $54 \%$ of samples) less than or equivalent to ca $5 \mu \mathrm{M}$. Likewise, D'Elia et al. (1983) observed that DSi concentrations occasionally approach levels that are potentially limiting to diatom growth in the mesohaline reach of the Bay.

Here we consider the effects of DSi depletion on phytoplankton production and community structure based on a 5 yr time-series conducted as part of the Chesapeake Bay Monitoring Program. Specifically, we address the potential of DSi-limited net community production (as indicated by the accumulation of phytoplankton biomass) during the spring bloom (AprilMay) and the relationship between DSi depletion and changes in floristic composition associated with the late May/early June transition from the spring biomass maximum to the summer productivity maximum.

\section{METHODS}

A total of 21 stations down the mainstem of Chesapeake Bay were used in the analysis (Fig. 1). 
Stations throughout the Bay were usually sampled over a 4 d period. Sampling was initiated in July 1984 and continues today; data analyzed here encompass the period July 1984 through December 1988. Water samples were collected twice monthly during March through October and monthly during November through February. DSi concentrations were analyzed using the Technicon Industrial Systems (1977) method, and dissolved inorganic phosphate (DIP) and dissolved inorganic nitrogen (DIN) were analyzed using the automated methods of the U.S. Environmental Protection Agency (1979) on a Technicon AutoAnalyzer. DIN concentrations were calculated from the sum of nitrate, nitrite and ammonia. Data from various depths at indi- vidual stations were averaged: mean surface layer concentrations were obtained using near-surface and above-pycnocline samples, and mean bottom layer concentrations were estimated using near-bottom and below-pycnocline samples.

The analysis focused upon 3 stations along the salinity gradient of the Bay. Stn 2.2 is in the upper oligohaline estuary and is dominated by nutrient inputs from the Susquehanna River (Schubel \& Pritchard 1986). Stn 4.2 is located in the mesohaline portion of the estuary where phytoplankton biomass and productivity attain seasonal maxima and riverine nutrient inputs are utilized to near depletion (Fisher et al. 1988, Malone et al. 1988). $\operatorname{Stn} 6.4$ is in the lower Bay where nutrient

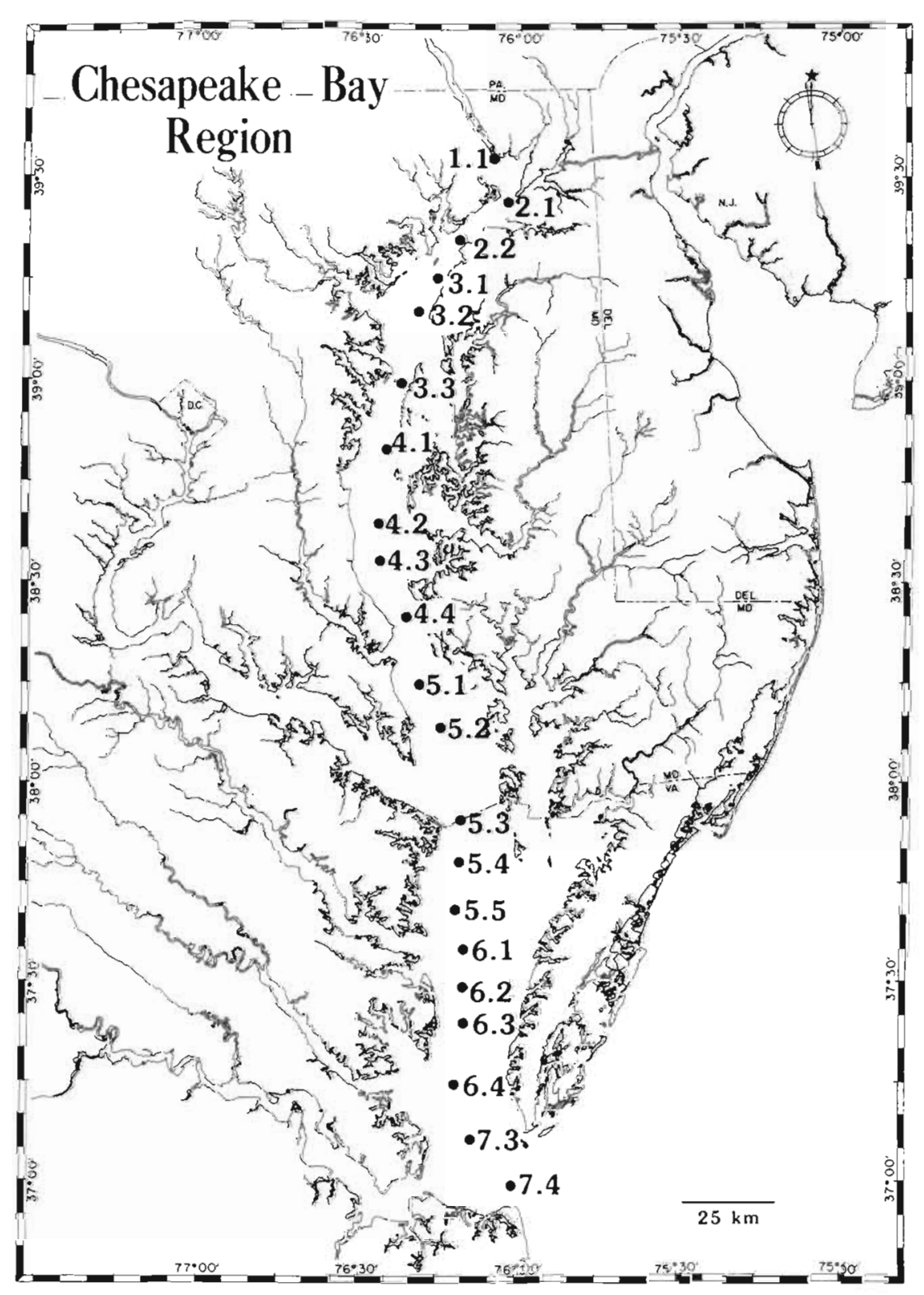

Fig. 1 Station locations in the mainstem of Chesapeake Bay 
depletion is most often observed (McCarthy et al. 1977. Fisher et al. 1988).

\section{RESULTS}

\section{Dissolved silicate distributions}

Annual cycles of DSi concentration varied with distance down the axis of Chesapeake Bay in terms of both amplitude and phasing (Fig. 2). Concentration maxima and minima decreased with distance from the riverine source. In the upper Bay, the distribution of DSi exhibited a winter maximum and a spring minimum (usually in May) followed by summer peaks and a secondary fall decline. Surface concentrations were equal to or higher than concentrations in bottom water. In contrast, peaks in the distribution of DSi at the mesohaline and lower Bay stations were highest during summer, with bottom water concentrations being equal
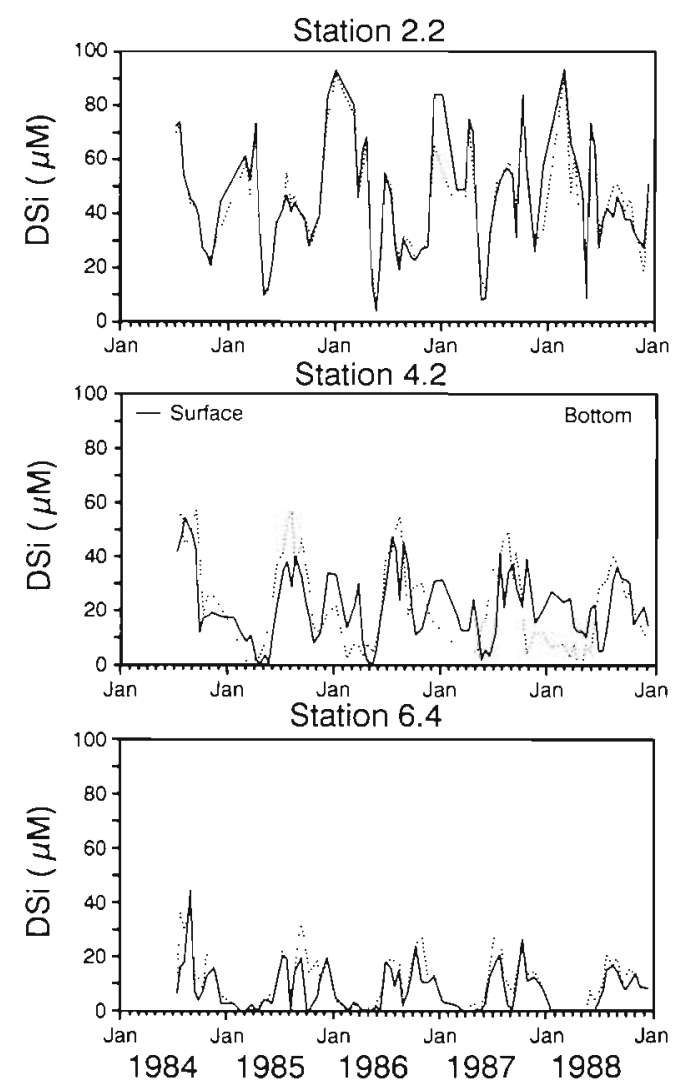

Fig. 2. Dissolved silicate (DSi) concentrations at selected stations in Chesapeake Bay from July 1984 through December 1988. Continuous line denotes average surface layer DSi concentrations and dotted line denotes average bottom layer DS concentrations. Stn 2.2 represents conditions in the upper Bay, Stn 4.2 conditions in the mesohaline mid-Bay, and Stn 6.4 conditions in the lower Bay to or higher than concentrations in the surface layer In general, DSi concentration in the surface layer began to decline earlier and remained lower longer with distance from the freshwater source, i.e. weeks in the mesohaline compared to months near the mouth of the Bay. Surface concentrations were often at $0.8 \mu \mathrm{M}$, the detection limit of the DSi analysis, in the surface layer of the mesohaline Bay for several weeks during spring. Surface distributions of DSi during the spring bloom were non-conservative, with DSi concentration approaching zero at salinities of 10 to $15 \%$ (Fig. 3). This pattern of rapid decline with time and salinity is indicative of rapid uptake by diatoms as chlorophyll biomass accumulated in the upper mesohaline reach of the Bay. Interannual variability is apparent in the timing, duration and areal extent of DSi depletion.

\section{Nutrient ratios}

The potential importance of DSi relative to DIN and DIP in limiting diatom production can be deduced from variations in molar ratios in the ambient concentrations of these nutrients in the water column (Hecky \& Kilham 1988, Howarth 1988). The Si:N:P ratio of marine diatoms is about 16:16:1 for nutrient-sufficient populations (Redfield et al. 1963, Brzezinski 1985). Thus, potential limitation by DSi is indicated by DSi:DIN and DSi:DIP ratios of less than 1 and 16, respectively.

During the period of the spring bloom, nutrient ratios in low-salinity waters near the head of the estuary suggest that DIP should be depleted before either DIN or DSi (Fig. 4). However, DSi decreased relative to DIP with distance (and increasing salinity) down the mainstem. In contrast, DSi was depleted relative to DIN throughout the Bay except during late spring in the lower Bay, when DSi:DIN was observed to increase with time rather than decrease as observed at the mesohaline and upper Bay stations. DSi depletion relative to DIN was especially pronounced at the mesohaline station where DSi:DIN was $<1$ and frequently $<0.1$ throughout the period (Fig. 4). DSi was not depleted relative to DIP until the end of the spring bloom period in the mesohaline (and then only in 1985 and 1986), but was consistently depleted relative to DIP at the lower Bay station.

\section{DISCUSSION}

\section{Factors controlling DSi concentrations}

Spatial variations in the annual DSi cycle reflect both the sources (freshwater runoff and benthic regeneration) and sinks (diatom uptake) of DSi. During winter 

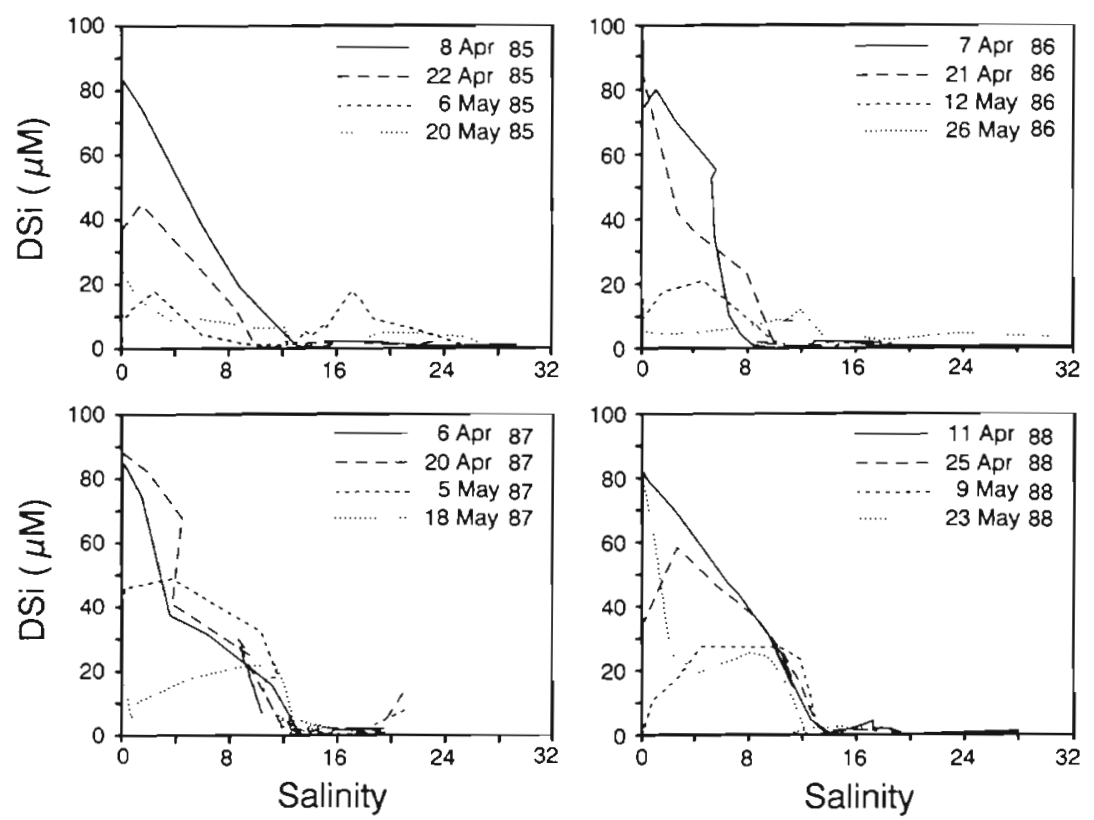

Fig. 3. Profiles of dissolved silicate (DSi) concentrations vs salinity (\%) during the spring biomass maximum in the surface layer. Dates in the legend coincide with the first day of sampling

and spring the predominant source to the Bay is freshwater runoff which peaks during the freshet (February to April). Based on changes in vertical distributions of DSi with salinity down the axis of the Bay, benthic flux of recycled diatom silica was the dominant source in the mesohaline Bay and may have been the dominant source throughout most of the year in the lower Bay (Figs. $2 \& 4$ ). The importance of the benthos in the recycling of nutrients in coastal marine systems is widely recognized (Nixon 1981, Boynton et al. 1982 , Pilson 1985). Maximum DSi concentrations in the mesohaline and lower Bay were reached during summer in bottom waters, when regenerative processes in the water column and sediment-water fluxes are likely to be highest (D'Elia et al. 1983, Boynton et al. 1989). Regeneration of particulate biogenic silica is strongly temperature-dependent as dissolution rates exponentially increase with temperature in accordance with the Arrhenius equation (Kamatani 1982).

Temporal and spatial variations in DSi also reflect seasonal patterns of diatom production. The lowest DSi concentrations in the mesohaline and lower Bay were observed in spring during the later stages of the spring biomass maximum (Anderson 1986, Malone 1992). Decreases in the concentration of DSi during fall and winter months were most likely a consequence of low freshwater input, declining inputs of DSi from benthic regeneration as temperature decreased (Boynton et al. 1989), and removal of DSi as the biomass of diatoms increased (Malone et al. 1988, Sellner \& Brownlee 1988). Although increases in diatom biomass have
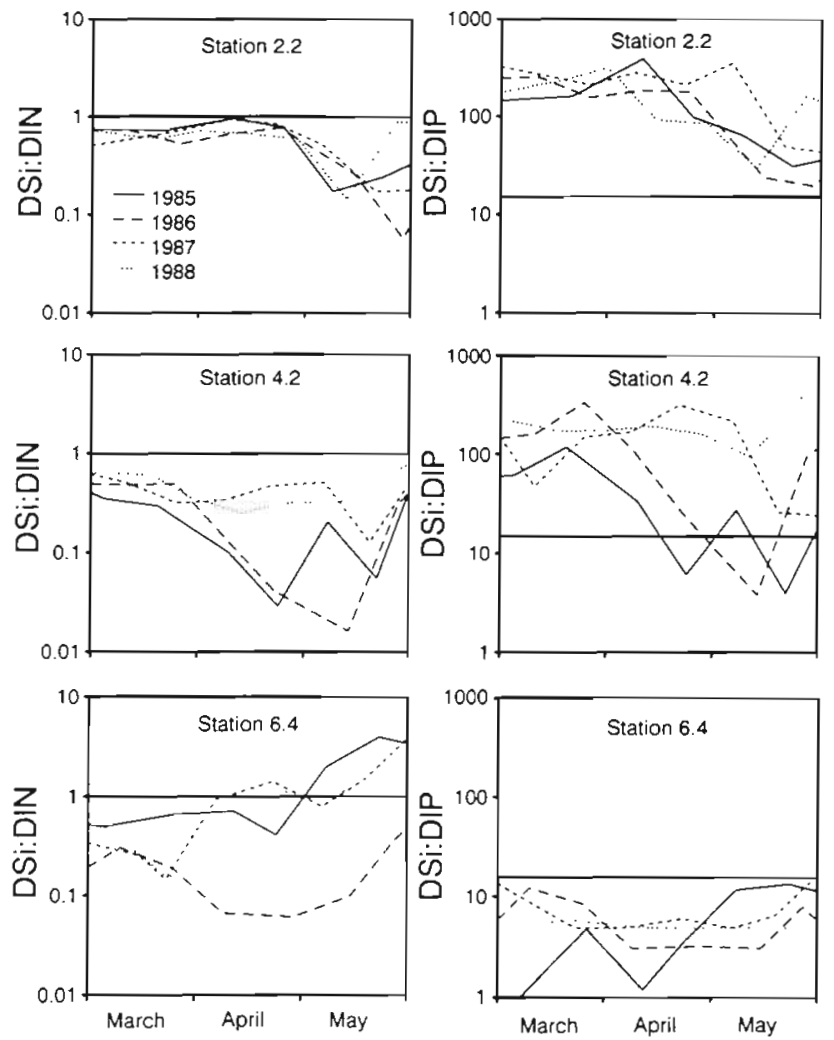

Fig. 4. DSi:DIN and DSi:DIP nutrient molar ratios for the midand lower Bay during the periods when DSi concentrations were low 
been observed during fall (Sellner et al. 1989), massive accumulations of diatom biomass did not occur and DSi was not depleted to limiting levels in surface waters. High grazing rates (White 1991, Malone 1992) and declining light levels coupled with intermittent mixing of the water column during fall wind events (Goodrich et al. 1987) may not allow bloom densities to form. The lower DSi concentrations observed in bottom waters relative to surface waters in the mesohaline Bay during winter and spring may reflect diatom uptake as well as the riverine source. DSi uptake by diatoms can proceed at substantial rates under low light and in the dark (Azam \& Chisholm 1976, Nelson et al. 1981, Brzezinski \& Nelson 1989).

\section{Influence on primary production: biomass limitation}

DSi limitation of diatom production arises when supply rates in the water column are low relative to its demand and in relation to other nutrients required during growth (Kilham 1971, Schelske \& Stoermer 1971, Officer \& Ryther 1980). Low DSi supply relative to uptake rates by diatoms can (1) limit increases in diatom biomass or growth rate and (2) may lead to a decline in diatom biomass due to high sinking rates of DSi-deficient populations (Bienfang et al. 1982). The selective effect of DSi on diatoms can have an important impact on the structuring of phytoplankton communities by selectively limiting diatom growth and increasing sedimentation rate.

DSi concentrations were sufficiently high throughout most of the Bay and throughout most of the year such that diatom production was probably not limited by DSi except during spring, when DSi was depleted to detection limits $(0.8 \mu \mathrm{M})$ over much of the mesohaline and lower Bay (Figs. $2 \& 3$ ). Low DSi concentrations coincide with a rapid decline in phytoplankton biomass and a shift from a diatom-dominated community to one dominated by cyanobacteria and other nondiatomaceous picoplankton (Malone et al. 1991). This may reflect the combined effects of a depletion of the standing stock of DSi and reduced riverine input as flow begins to decline following the spring freshet.

Low levels of DSi in the mesohaline reach of the Bay during spring have been reported (D'Elia et al. 1983, Sellner \& Kachur 1987). D'Elia et al. (1983) hypothesized that DSi limitation of diatom growth seems unlikely because of high DSi supply rates from sediment-water fluxes. However, sediment DSi flux rates are low during spring (Fig. 2; Boynton et al. 1989). Prior to the present analysis low levels of DSi over extensive areas of the Bay during spring months have not been reported. Although low DSi concentrations do not rule out limitation of primary production by other nutrients, high DIN concentrations and DSi:DIN ratios less than 1 (Fig. 4) suggest that DSi was more important in limiting the accumulation of diatom biomass during the spring biomass maximum. DIP concentrations were low during spring (Magnien et al. 1987), and bioassay experiments in Chesapeake Bay (D'Elia et al. 1986), which did not evaluate DSi, suggest that phosphorus may limit phytoplankton productivity during spring. However, DSi:DIP ratios were less than Redfield ratios during winter and spring in the lower Bay and often fall below Redfield ratios in the mesohaline Bay, indicating that diatom production probably became DSi-limited during spring.

\section{Magnitude of spring diatom biomass: influence of river flow}

Previous research has shown that accumulations of biomass in the mesohaline Bay were related to the flow of the Susquehanna River (Malone et al. 1988), suggesting that riverine nutrient inputs regulate the production of phytoplankton biomass, a conclusion that is consistent with the observation that both river flow and the accumulation of phytoplankton biomass were unusually low during spring 1989 (Magnien 1990).

In order to evaluate the importance of river inputs during the freshet relative to prior inputs, standing stocks of DSi within the Bay were compared to projected inputs of new DSi during the freshet. Standing stocks of DSi available for diatom production were calculated using spatially weighted, average (1985 to 1988) winter maximum DSi concentrations (January in the lower Bay and February in the upper and mesohaline Bay). DSi standing stocks in surface waters were estimated to be $390 \times 10^{6} \mathrm{~mol} \mathrm{Si}$ and total standing stocks from both surface and bottom waters were calculated to be $880 \times 10^{6} \mathrm{~mol} \mathrm{Si}$.

To determine the projected inputs of DSi we assumed that the sole source of allochthonous DSi to the mainstem Bay is freshwater input from the Susquehanna River during the freshet (February to May). Inputs from other riverine sources were assumed to be negligible. The projected average input of new DSi to the Bay during the freshet by the Susquehanna River has been estimated from loading calculations for the period 1978 to 1988 to be $1100 \times 10^{6} \mathrm{~mol} \mathrm{Si}$ (Summers 1990). This estimate is $62 \%$ of the Susquehanna River annual load (D'Elia et al. 1983).

Because DSi is almost entirely removed from the estuary in most years during the spring bloom, we will assume that all DSi within the Bay and all projected inputs were removed to produce diatoms. Diatom production from standing stocks of DSi (390 to $880 \times 10^{6}$ mol Si), added to the DSi brought into the Bay during 
the spring freshet $\left(1100 \times 10^{6} \mathrm{~mol} \mathrm{Si}\right)$, allows for the production of 1490 to $1980 \times 10^{6} \mathrm{~mol}$ of diatom Si. Thus, DSi standing stocks within the Bay can support only 26 to $44 \%$ of total potential diatom production during spring in an average year; the remainder must be supplied by new DSi inputs from the watershed or from regeneration within the Bay. This comparison highlights the importance of riverine inputs in controlling the magnitude of the spring diatom bloom.

The influence of river flow on diatom production also has important implications for annual variations in the accumulation of biomass during spring. In years of high river flow and, therefore, high loading of new DSi, more DSi would be available for diatom production and a larger spring accumulation of diatom biomass. In years of low river flow, with low supply rates of new DSi, the magnitude of spring accumulation of biomass should be smaller.

\section{Influence on primary production: decline of the spring biomass maximun}

Low DSi concentrations throughout extensive portions of Chesapeake Bay may also be an important factor in the decline of the spring biomass maximum. Coincident with declining DSi levels in April and May, sediment traps in the mesohaline reach of the Bay collect relatively large amounts of particulate carbon, nitrogen, phosphorus and biogenic silica (Boynton et al. 1989), and water column chlorophyll concentrations markedly decline (Malone et al. 1988). Nutrient limitation, especially by DSi, is often the cause of termination of diatom blooms (Lund 1950 . Schelske \& Stoermer 1971); diatom blooms limited by DSi supply rates can be sustained by additions of new DSi (Doering et al. 1989). It is our hypothesis that the collapse of the spring bloom occurs as a consequence of DSi deficiency and associated increases in sedimentation rate. The possibility of DSi limitation in the Bay also is of interest because of its effect on phytoplankton sinking rates. Sinking rates of diatoms are particularly sensitive to DSi depletion (Titman \& Kilham 1976, Bienfang et al. 1982). Bienfang et al. (1982) found that DSi limitation, but not nitrogen or phosphorus limitation, resulted in increased sinking rates of 3 species of marine diatoms. Limitation of diatoms by DSi, therefore, may partially explain the rapid decrease in chlorophyll in spring and may be a significant factor in the termination of the spring biomass maximum.

\section{CONCLUSIONS}

Spatial and temporal variations in mainstem DSi concentrations demonstrate that distributions were domi- nated by river flow during winter-spring in the upper and mesohaline Bay and by benthic regeneration during summer in the lower Bay. This pattern of mesoscale temporal and spatial separation between input and regeneration is consistent with the conceptual input-uptake-sedimentation-regeneration model (Kemp \& Boynton 1984, Fisher et al. 1988, Malone et al. 1988) described for Chesapeake Bay. Variations in DSi concentrations and in nutrient ratios consistently indicate that DSi approached depletion before either $\mathrm{N}$ or $\mathrm{P}$ on a seasonal scale and the space scale of the Bay. DSi may control the magnitude of diatom production during the spring bloom and the flux of phytoplankton biomass to the benthos. DSi concentrations are reduced to levels potentially limiting to diatom production annually at salinities greater than $10 \%$ during the spring biomass maximum.

The potential limitation of the spring biomass maximum by DSi has important implications for nutrient dynamics and oxygen depletion in Chesapeake Bay. Summer anoxia has been linked to nutrient loading via accumulation of phytoplankton biomass during spring; accumulations of organic matter during spring fuel summer oxygen depletion (Malone et al. 1988, Malone 1992). If DSi supply rates and not DIP and/or DIN limits the magnitude of the spring diatom bloom, changes in the extent of anoxia may partly result from interannual variations in DSi inputs to the Bay during this period. The subsequent regeneration of those nutrients during decomposition of this freshly deposited organic matter influences the quantity of nutrients available to be recycled for summer production. Thus, it is important to understand the pathways and processes leading to the accumulation of diatom biomass during spring.

The potential limitation of the spring biomass maximum by DSi also has important implications for effective nutrient management strategies. It suggests that $\mathrm{N}$ and $P$ loading has exceeded the assimilation capacity of the system, forcing, in effect, DSi limitation. DSi inputs to the Bay are uncontrollable and result primarily from weathering reactions. In order to reduce the size of the spring diatom bloom, and attendant summer anoxia, management strategies must continue to reduce $\mathrm{N}$ and/or $\mathrm{P}$ such that accumulations of biomass are not DSi-limited, but rather $\mathrm{N}$ - or P-limited.

Acknowledgements. Nutrient data, collected under the auspices of the U.S. Environmental Protection Agency's Chesapeake Bay Program, were kindly provided with permission of Robert Magnien of the Maryland Department of the Environment and Rick Hoffman of the Virginia State Water Control Board. We thank these individuals for releasing the data, and Rich Batuik and John Posey of the U.S. Environmental Protection Agency for their assistance in acquiring the data. Sue Banahan, Walter Boynton, Mark Brzezinski, Tom 
Fisher, David Nelson, Kevin Sellner and Steve Smith provided valuable comments on earlier drafts of this manuscript. This research was supported in part by grants from Maryland Sea Grant (R/DO-19) and the NSF-sponsored LMER project (BSR$8814272)$

\section{LITERATURE CITED}

Anderson, G. F. (1986). Silica, diatoms and a freshwater productivity maximum in Atlantic coastal plain estuaries, Chesapeake Bay. Estuar coast. Shelf Sci. 22: 183-197

Azam, F., Chisholm, S. W. (1976). Silicic acid uptake and incorporation by natural phytoplankton populations. Limnol. Oceanogr. 21: 427-435

Bienfang, P. K., Harrison, P. J., Quarmby, L. M. (1982). Sinking rate response to depletion of nitrate, phosphate and silicate in four marine diatoms. Mar Biol. 67: 295-302

Boynton, W. R., Garber, J. H., Barnes, J. M., Matteson, L., Stammerjohn, S., Watts, J. L. (1989). Ecosystem Process Report Level 1, Report 6. (UMCEES CBL Ref. No. 89-089). Maryland Department of the Environment, Baltimore

Boynton, W. R., Kemp, W. M., Keefe, C. W. (1982). A comparative analysis of nutrients and other factors influencing estuarine phytoplankton production. In: Kennedy, V S. (ed.) Estuarine comparisons. Academic Press, New York, p. $69-90$

Brzezinski, M. A. (1985). The Si:C:N ratio of marine diatoms: interspecific variability and the effect of some environmental variables. J. Phycol. 21: 347-357

Brzezinski, M. A., Nelson, D. M. (1989). Seasonal changes in the silicon cycle within a Gulf Stream warm-core ring. Deep Sea Res. 36: 1009-1030

D'Elia, C. F., Nelson, D. M., Boynton, W. R. (1983). Chesapeake Bay nutrient and plankton dynamics: III. The annual cycle of dissolved silicon. Geochim. cosmochim. Acta 47: 1945-1955

D'Elia, C. F., Sanders, J. G., Boynton, W. R. (1986). Nutrient enrichment studies in a coastal plain estuary: phytoplankton growth in large-scale, continuous culture. Can. J. Fish. Aquat. Sci. 43: $397-406$

Doering, P. H., Oviatt, C. A., Beatty, L. L., Banzon, V. F., Rice, R. Kelly, S. P., Sullivan, B. K., Frithsen, J. B. (1989). Structure and function in a model coastal ecosystem: silicon, the benthos and eutrophication. Mar Ecol. Prog. Ser. 52: $287-299$

Fisher, T R. Jr, Harding, L. W. Jr, Stanley, D. W., Ward, L. G. (1988). Phytoplankton, nutrients, and turbidity in the Chesapeake, Delaware, and Hudson estuaries. Estuar. coast. Shelf Sci. 27: 61-93

Goodrich, D. M., Boicourt, W. C., Hamilton, P., Pritchard, D. W. (1987). Wind-induced destratification in Chesapeake Bay. J. phys. Oceanogr. 17. 2232-2240

Hecky, R. E., Kilham, P. (1988). Nutrient limitation of phytoplankton in freshwater and marine environments: a review of recent evidence on the effects of enrichment. Limnol. Oceanogr. 33: 796-822

Howarth, R. W. (1988). Nutrient limitation of net primary production in marine ecosystems. Ann. Rev. Ecol. Syst. 19: 89-110

Kamatani, A. (1982). Dissolution rates of silica from diatoms decomposing at various temperatures. Mar. Biol. 68: 91-96

Kilham, P. (1971). A hypothesis concerning silica and the freshwater planktonic diatoms. Limnol. Oceanogr. 16: $10-18$

Kemp, W M., Boynton, W R. (1984). Spatial and temporal coupling of nutrient inputs to estuarine primary production: the role of particulate transport and decomposition. Bull. mar Sci. 35: 522-535

Lund, J. W. G. (1950). Studies on Asterionella formosa Hass. II. Nutrient depletion and the spring maximum. J. Ecol. 38 $1-35$

Magnien, R. E. (1990). Spring phytoplankton bloom failure in Chesapeake Bay and impact upon hypoxia. EOS 71185

Magnien, R. E., Vaas, P. A., Austin, D. K., Dobler, E. A., Michael, B. D. (1987). Maryland Department of the Environment, Chesapeake Bay Water Quality Monitoring Program. Chemical/Physical Properties Component. Level I Data Report. Baltimore

Malone, T. C. (1992). Effects of water column processes on dissolved oxygen: nutrients, phytoplankton, and zooplankton. In: Smith, D., Leffler, M., Mackiernan, G. (eds.) Oxygen dynamics in Chesapeake Bay. A synthesis of results. Maryland Sea Grant, College Park, p. 61-148

Malone, T C., Crocker, L. H., Pike, S. E., Wendler, B. W (1988). Influences of river flow on the dynamics of phytoplankton production in a partially stratified estuary. Mar. Ecol. Prog. Ser. 48: 235-249

Malone, T C., Ducklow, H. W., Peele, E. R., Pike, S. E. (1991). Picoplankton carbon flux in Chesapeake Bay. Mar. Ecol. Prog. Ser. 78: 11-22

Malone, T C., Garside, C., Neale, P. J. (1980). Effects of silicate depletion on photosynthesis by diatoms in the plume of the Hudson River Mar Biol. 58: 197-204

McCarthy, J. J., Taylor, W R., Loftus, M. E. (1977). Nitrogenous nutrition of the plankton in the Chesapeake Bay. I. Nutrient availability and phytoplankton preferences. Limnol. Oceanogr 22: 996-1011

Nelson, D. M., Goering, J. J., Boisseau, D. W (1981). Consumption and regeneration of silicic acid in three coastal upwelling systems. In: Richards, F. A. (ed.) Coastal upwelling. Coastal and estuarine sciences I. American Geophysical Union, Washington, D.C., p. 242-256

Nixon, S. W. (1981). Remineralization and nutrient cycling in coastal marine ecosystems. In: Neilson, B. J., Cronin, L. E. (eds.) Estuaries and nutrients. Humana Press, Clifton, NJ, p. $111-138$

Officer, C. B., Ryther, J. H. (1980). The possible importance of silicon in marine eutrophication. Mar. Ecol. Prog. Ser 9: 91-94

Pilson, M. E. Q. (1985). Annual cycles of nutrients and chlorophyll in Narragansett Bay, Rhode Island. J. mar. Res. 43: 849-873

Redfield, A. C., Ketchum, B. H., Richards, F. A. (1963). The influence of organisms on the composition of seawater. In: Hill, M. N. (ed.) The sea, Vol. 2. John Wiley \& Sons, New York, p. 26-77

Schelske, C. L., Stoermer, E. F. (1971). Eutrophication, silica depletion and predicted changes in algal quality in Lake Michigan. Science 173: 423-424

Schubel, J. R., Pritchard, D. W. (1986). Responses of upper Chesapeake Bay to variations in discharge of the Susquehanna River. Estuaries 9: 236-249

Sellner, K. G., Brownlee, D. C. (1988). Maryland Department of the Environment, Chesapeake Bay Water Quality Monitoring Program, Phytoplankton and Microzooplankton Component Data Summary. Baltimore

Sellner, K. G., Brownlee, D. C., Brownlee, S. G. (1989). Maryland Department of the Environment, Chesapeake Bay Water Quality Monitoring Program, Phytoplankton and Microzooplankton Component. Baltimore

Sellner, K. G., Kachur, M. E. (1987). Phytoplankton: relationships between phytoplankton, nutrients, oxygen flux and 
secondary producers. In: Heck, K. L. Jr (ed.) Lecture notes on coastal and estuarine studies, ecological studies in the middle reach of Chesapeake Bay. Springer-Verlag, New York, p. 12-37

Summers, R. (1990). Maryland Department of the Environment, Chesapeake Bay Water Quality Monitoring Program, River Input Monitoring Component Report. Baltimore

Technicon Industrial Systems (1977). Silicates in water and seawater. Industrial Method No. 186-72W/B. Technicon Industrial Systems, Terrytown, NY

This article was presented by D. M. Nelson, Corvallis, Oregon, USA
Titman, D., Kilham, P. (1976). Sinking in freshwater phytoplankton: some ecological implications of cell nutrient status and physical mixing processes. Limnol. Oceanogr. 21: $409-417$

White, T. R. (1991). Seasonal study of zooplankton dynamics in the mesohaline Chesapeake Bay. Ph.D. dissertation, The University of Maryland, College Park

U.S. Environmental Protection Agency (1979). Methods for the Chemical Analysis of Water and Wastes. U.S. EPA-600/479-020. Environmental Monitoring and Support Laboratory, Cincinnati

Manuscript first received: March 10, 1991

Revised version accepted: February 13, 1992 